\title{
Heavy Metal Contents of Melissa Which is Sold in Herbalists
}

\author{
Yavuz Bülent Köse*, Merve Uzun, Nagehan Saltan \\ Anadolu University, Faculty of Pharmacy, Department of Pharmaceutical Botany, 26470, Eskişehir, TURKEY.
}

\begin{abstract}
The purpose of this study is to determine the heavy metal content that is important in human health and the plants sold as Melissa L. in herbalists. Plant samples were purchased from 14 different herbalist and specimens were identified by Flora of Turkey. Heavy metal contents ( $\mathrm{Fe}, \mathrm{Co}, \mathrm{Mn}, \mathrm{Zn}, \mathrm{Al}, \mathrm{Cd}$ ) and some nutrients ( $\mathrm{Na}, \mathrm{K}, \mathrm{Ca}, \mathrm{Mg}$ ) were identified by the ICP-OES method. As a result of the diagnoses, 4 of 14 samples were Melissa officinalis L. and others were identified as Lippia citriodora. According to ICP analysis, $\mathrm{Zn}, \mathrm{Cd}$ and $\mathrm{Co}$ were not found in any sample. Other elements were found to be Al 200.93-695.29 mg/kg, Fe 4.51-339.37 mg/kg, Mn 1.61-73.59 mg/kg, Mg $3611.17-10001.73 \mathrm{mg} / \mathrm{kg}$, Ca $9727.78-25435.9 \mathrm{mg} / \mathrm{kg}$, K 10484.44-21975.71 mg/ $\mathrm{kg}, \mathrm{Na} 176.78-524.97 \mathrm{mg} / \mathrm{kg}$, respectively. Fe, Ca and $\mathrm{Mg}$ has been found above the level of toxic effects in terms of human health, while other elements were within the optimum limit.
\end{abstract}

Keywords: Melissa, ICP, Heavy Metal, Herbalists, Turkey.

\section{INTRODUCTION}

Lamiaceae is a family of flowering plants which contains about 236 genera and 7200 species. ${ }^{1}$ Melissa officinalis L. (Lemon balm), is a member of Lamiaceae, is one of the important medicinal plant species. Lemon balm is distributed in Mediterranean countries including the coastal regions of Turkey and southern Alpine regions. ${ }^{2,3}$ Three subspecies of $M$. officinalis growing in Turkey; subsp. officinalis, subsp. inodora and subsp. altissima. Besides, only subsp. officinalis has commercial value and the characteristic odor of lemon. ${ }^{4,5,6}$ Lemon balm ( $M$. officinalis L.), in other words "bee herb or sweet balm" is a medicinal plant from ancient time until now and is used for the treatment of mental and CNS diseases, cardiovascular and respiratory problems, various cancers, and as a memory enhancer, cardiotonic, anti-depressant, sleeping aid and antidote in folk medicine. ${ }^{7,8,9}$ In addition, recent data have supported $M$. officinalis has a protective role against Alzheimer disease. ${ }^{10,11}$ Dried or fresh leaves and the top aerial section of the plant are the parts which are used as medicine.

Heavy metal contents of the medicinal herbs change depend on climatic factors, plant species, vegetation period, air pollution, and other environmental factors. ${ }^{12,13}$ The certain permissible limits of metallic and non-metallic elements are necessary for the healthy human body. However, medicinal treatments with herbs and their extracts could be dangerous not only for the pharmacological side effects but also contents of heavy metals and other impurities. ${ }^{14}$ Thus medicinal raw materials should be controlled for the levels of the contaminant. ${ }^{15,16}$ In Turkey, herbalists collect the wild medicinal plants without growing and developing controls. The factor is the major reason for the species extinction.

The purpose of the study is to determine the heavy metal contents of Melissa sold in the herbalists for human health. The mineral contents of Melissa were evaluated for Fe
DOI: 10.5530/ijper.51.3s.16 Correspondence: Yavuz Bülent Köse, Anadolu University, Faculty of Pharmacy, Department of Pharmaceutical Botany, 26470, Eskişehir, TURKEY Phone no:

+9022233505810/3708 E-mail: ybkose@anadolu. edu.tr 
(iron), $\mathrm{Co}$ (cobalt), $\mathrm{Mn}$ (manganese), $\mathrm{Zn}$ (zinc), $\mathrm{Al}$ (aluminium), $\mathrm{Cd}$ (cadmium), $\mathrm{Na}$ (sodium), $\mathrm{K}$ (potassium), $\mathrm{Ca}$ (calcium), and $\mathrm{Mg}$ (magnesium). The results have been compared with weighted values found in plants as well as settled limits for herbal medicines and derived products. The measurements were performed with an inductively coupled plasma optical emission spectrometer (ICP-OES).

\section{MATERIAL AND METHODS}

\section{Plant material}

Plant samples were purchased from 14 different herbalists in Turkey and identification of the specimens were made with Flora of Turkey (Table 1). ${ }^{4}$

The compositions of the 14 different herbal species were evaluated for heavy metal contents (Fe, Co, Mn, $\mathrm{Zn}, \mathrm{Al}, \mathrm{Cd})$ and some nutrients $(\mathrm{Na}, \mathrm{K}, \mathrm{Ca}, \mathrm{Mg}$ ) with ICP-OES (Inductively Coupled Plasma-Optical Emission Spectrometry) technique.

\section{RESULTS AND DISCUSSION}

Due to the volatile oil content as Melissa 2 different species are sold in herbalists, Turkey. According to botanical diagnoses, 4 samples were identified as $M$. officinalis and others were Lippia citriodora of the 14 plant samples. Depending to ICP analysis, $\mathrm{Zn}, \mathrm{Cd}$ and $\mathrm{Co}$ were not

\begin{tabular}{|c|c|}
\hline \multicolumn{2}{|c|}{ Table 1: List of herbalists } \\
\hline 1 & Yemen Baharat- Denizli \\
\hline 2 & Temiz iş- Ege Bölgesi \\
\hline 3 & Temiz iş- Ege Bölgesi \\
\hline 4 & Asya Baharat- İzmir \\
\hline 5 & Şifa Baharat- Uludağ (Bursa) \\
\hline 6 & Murat Baharat- Karden baharat \\
\hline 7 & Eskişehir Baharat- Konya \\
\hline 8 & Nasip Baharat- Eskişehir \\
\hline 9 & Doğa Baharat- İzmir \\
\hline 10 & Hisarlı kuru kahve- Eskişehir \\
\hline 11 & Flamingo Baharat- Didim (Aydın) \\
\hline 12 & Flamingo Baharat- Antalya \\
\hline 13 & Arifoğlu Baharat- Eskişehir \\
\hline 14 & Korkuteli Baharat- Denizli \\
\hline
\end{tabular}

found in any sample, and other found elements were Al 200.93-695.29 mg/kg, Fe 4.51-339.37 mg/kg, Mn 1.61-73.59 mg/kg, Mg 3611.17-10001.73 mg/kg, Ca 9727.78-25435.9 mg/kg, K 10484.44-21975.71 mg/kg, $\mathrm{Na} 176.78-524.97 \mathrm{mg} / \mathrm{kg}$, respectively (Table 2).

Found rates of the $\mathrm{Fe}, \mathrm{Ca}$ and $\mathrm{Mg}$ was above the toxic levels for human health, while other elements were within the optimum limit. The recommended intakes of essential secondary plant nutrients / trace elements

\begin{tabular}{|c|c|c|c|c|c|c|c|c|c|c|}
\hline Sample & $\mathrm{Zn}$ & Al & $\mathrm{Cd}$ & Co & $\mathrm{Fe}$ & Mn & Mg & $\mathrm{Ca}$ & K & $\mathrm{Na}$ \\
\hline 1. (L. citriodora) & - & 608.61 & - & - & 303.45 & 20.83 & 4737.71 & 23950.28 & 10485.44 & 321.09 \\
\hline 2. (M. officinalis) & - & 494.97 & - & - & 146.78 & 73.59 & 7694.17 & 25435.9 & 11106.63 & 247.02 \\
\hline 3. (L. citriodora) & - & 342.74 & - & - & 69.34 & - & 3839.11 & 12493.94 & - & 219.61 \\
\hline 4. (L. citriodora) & - & 259.01 & - & - & 6.14 & - & 3819.44 & 17804.36 & 13849.05 & 218.10 \\
\hline 5. (L. citriodora) & - & 258.53 & - & - & - & - & 4322.73 & 17055.14 & 12450.88 & 235.41 \\
\hline 6. (L. citriodora) & - & 200.93 & - & - & 75.57 & 1.61 & 4407.18 & 18593.94 & 15603.35 & 280.58 \\
\hline 7. (M. officinalis) & - & 521.50 & - & - & 90.36 & - & 5623.95 & 9727.78 & 15102.37 & 199.10 \\
\hline 8. (L. citriodora) & - & 678.62 & - & - & 339.37 & 14.13 & 5515.28 & 25013.01 & - & 176.78 \\
\hline 9. (L. citriodora) & - & 695.29 & - & - & 106.84 & - & 4356.32 & 18874.56 & 14510.77 & 217.94 \\
\hline 10. (L. citriodora) & - & 380.95 & - & - & - & - & 4341.19 & 16507.05 & 15070.32 & 229.14 \\
\hline 11. (L. citriodora) & - & 448.52 & - & - & - & - & 4224.65 & 20628.89 & 17842.49 & 467.44 \\
\hline 12. (L. citriodora) & - & 648.96 & - & - & 38.81 & 19.83 & 10001.73 & 23150.44 & 15539.38 & 207.16 \\
\hline 13. (M. officinalis) & - & 461.91 & - & - & - & - & 3611.17 & 12770.96 & 18557.25 & 524.97 \\
\hline 14. (M. officinalis) & - & 535.57 & - & - & 4.51 & - & 5014.65 & 16674.36 & 21975.71 & 213.82 \\
\hline
\end{tabular}


( $\mathrm{Zn}, \mathrm{Fe}, \mathrm{Mn}, \mathrm{Cu}, \mathrm{Cr}$ and $\mathrm{Ni}$ ) do not exceed to $0.01 \%$ of body weight. ${ }^{17}$

The daily intake of Fe is $10 \mathrm{mg}$ for an adult male, $15-18 \mathrm{mg}$ for females and 27-30 mg for pregnant women. ${ }^{18}$ The daily intake of $\mathrm{Mg}$ is $300-420 \mathrm{mg}$ in adults. ${ }^{19}$ Medicinal raw plant materials do not have any standardization establish permissible levels for metals. Only World Health Organization (WHO) mentions maximum permissible levels for $\mathrm{As}, \mathrm{Cd}$, and $\mathrm{Pb}$ which amount to 1.0, 0.3 and $10 \mathrm{mg} / \mathrm{kg}$, respectively in raw materials. ${ }^{20}$

According to the Turkish Food Codex (TFC), the maximum levels of $\mathrm{As}, \mathrm{Cu}, \mathrm{Zn}, \mathrm{Cd}$, and $\mathrm{Pb}$ may not exceed $0.1,2,2,0.01$, and $0.1 \mathrm{mg} / \mathrm{kg}$ (ppm), respectively, in food. ${ }^{21}$

Pellerano et al. (2011) stated the concentration of fourteen micro and macro minerals of 5 different medicinal plants taken from regional markets, mainly in San Luis province (Argentina) in both crude drugs and infusions and reported the highest $\mathrm{Mg}\left(4.03 \mathrm{mg}^{\mathrm{g}-1}\right), \mathrm{K}\left(16.90 \mathrm{mg}^{\mathrm{g}-1}\right)$ and Fe $\left(0.97 \mathrm{mg} \mathrm{g}^{-1}\right)$ concentration for M. officinalis. ${ }^{22}$

\section{CONCLUSION}

Even though some of the samples sold in the herbalist are packaged and labelled, some have been turned into bundles and some have been sold out in pieces. It has been determined that some of these samples sold as Melissa do not belong to $M$. officinalis.

In order to determine the quality of medical plants and to prevent human health from adversely affecting them, it is necessary to determine the heavy metal concentrations and make them a criterion for selling.

\section{ACKNOWLEDGEMENT}

The study has been supported by Anadolu University Scientific Research Committee (Project No. 1605S492).

\section{CONFLICT OF INTEREST}

None

\section{ABBREVIATION USED}

$\mathrm{Mg} / \mathrm{kg}$ : miligram/kilogram; $\mathrm{Mg} \mathrm{g}^{-1}$ : miligram/gram ; $\mu \mathrm{g} / g r:$ microgram/gram; mg: miligram; ppm: Parts per million; CNS: Central Nervous System; Fe: iron; Co: cobalt; Mn: manganese; Zn: zinc; Al: aluminium; Cd: cadmium; Na: sodium; K: potassium; Ca: calcium; Mg: magnesium; As: arsenic; ICP-OES: Inductively Coupled Plasma-Optical Emission Spectrometry; WHO: Only World Health Organization ; TFC: Turkish Food Codex

\section{REFERENCES}

1. Raja R. Medicinally Potential Plants of Labiatae (Lamiaceae) Family: An Overview. Res J Med Plant 2012;6(3):203-13.

2. Baytop T. Türkiye'de Bitkilerle Tedavi. İ.Ü. Yayınları No: 3255. İstanbul; 1984.

3. Ceylan A. Tıbbi Bitkiler-II (Uçucu Yağ Bitkileri). E.Ü. Ziraat Fakültesi Yayını No: 481. İzmir; 1997.

4. Mill RR. Flora of Turkey and the East Aegean Islands. Davis PH, editör. Edinburgh University Press. Edinburgh, Great Britain; 1982.

5. Baytop A. Farmasötik Botanik Ders Kitabı. İ.Ü Yayınları No: 3637. İstanbul; 1991.

6. Craker LE, Simon, JE. Herbs, Spices, and Medicinal Plants: Recent Advances in Botany, Horticulture, and Pharmacology. Vol. 2. Oryx Press. USA; 1992.

7. Shakeri A, Sahebkar A, Javadi B. Melissa officinalis L. - A review of its traditional uses, phytochemistry and pharmacology. J Ethnopharmacol. 2016;188:204-28.

8. Veisi M, Shahidi S, Komaki A, Sarihi A. Assessment of aqueous extract of Lemon verbena on anxiety-like behavior in rats. J Pharm Negative Results. 2015;6(1):37-9.

9. Shekarchi M, Hajimehdipoor H, Saeidnia S, Gohari AR, Hamedani MP. Comparative study of rosmarinic acid content in some plants of Labiatae family. Phacog Mag. 2012;8(29):37-41.

10. Dos Santos-Neto LL, de Vilhena Toledo MA, Medeiros-Souza P, de Souza $\mathrm{GA}$. The use of herbal medicine in Alzheimer's disease-a sistematic review. Evid Based Complement Alternat Med. 2006;3(4):441-5.

11. Martins EN, Pessano NT, Leal L, Roos DH, Folmer V, Puntel GO, et al. Protective effect of Melissa officinalis aqueous extract against Mn-induced oxidative stress in chronically exposed mice. Brain Res Bull. 2012;87(1):74-9.

12. Sovljanski R, Lazic S, Macko V, Obradovic S. Heavy metal content in medicinal and spice plants cultivated in Yugoslavia. Herba Hung. 1990;29(3):59.

13. Das K, Dang R, Sutar GV, Einstein JV, Paul RK, Karak T. Influence of Metals In Soil on The Comparative Phytochemical Characterization and Antioxidant Study of Indian Golden Shower (Cassia Fistula). Indian J Pharm Educ. 2016;50(3):266-79.

14. Annan K, Kojo AI, Cindy A, Samuel AN, Tunkumgnen BM. Profile of heavy metals in some medicinal plants from Ghana commonly used as components of herbal formulations. Pharmacognosy Res. 2010;2(1):41-4.

15. Baranowska I, Srogi K, Wlochowicz A, Szczepanik K. Determination of heavy metal contents in samples of medicinal herbs. Pol J Environ Stud. 2002;11(5):467-1.

16. Annan K, Dickson RA, Amponsah IK, Nooni IK. The heavy metal contents of some selected medicinal plants sampled from different geographical locations. Pharmacognosy Res. 2013;5(2):103-8.

17. Imelouane B, Tahri M, Elbastrioui M, Aouinti F, Elbachiri A. Mineral contents of some medicinal and aromatic plants growing in Eastern Morocco. J. Mater. Environ. Sci. 2011;2(2):104-1.

18. Samur G. Vitamins, Minerals and Healthy. Ministry of Health. Klasmat Publishing: Ankara; 2008.

19. Vormann J. Magnesium: Nutrition and metabolism. Mol Aspects Med. 2003;24(1-3):27-37.

20. Basgel S, Erdemoglu SB. Determination of mineral and trace elements in some medicinal herbs and their infusions consumed in Turkey. Sci Total Environ. 2006;359(1):82-9.

21. TFC: Setting maximum levels for certain contaminants in foodstuffs. Turkish Food Codex; 2002.

22. Pellerano RG, Téves MR, Caffi ni NO, Marchevsky EJ. Evaluation of macro and microminerals in crude drugs and infusions of five herbs widely used as sedatives. Braz. J. Pharmacogn. 2011;21(6):1144-9. 
PICTORIAL ABSTRACT

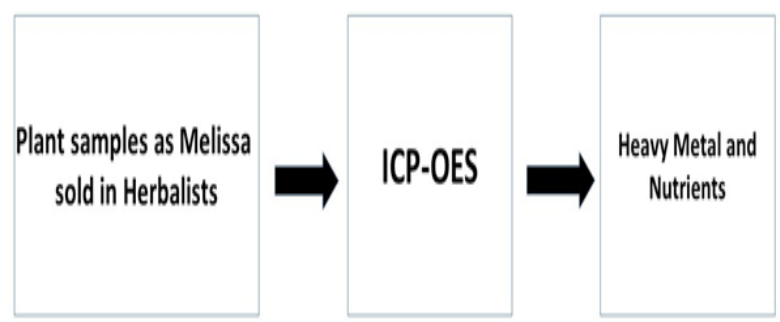

\section{About Authors}

Dr. Yavuz Bülent Köse: Received his M.sc degree in 2001 from Osmangazi University Graduate School of Science. He received his Ph.D. from the Anadolu University Anadolu University Graduate School of Science. Now he is Assoc. Prof. Dr. of Anadolu University Faculty of Pharmacy, Pharmaceutical Botany Department. He has published about 40 academic papers in reputed Journals.

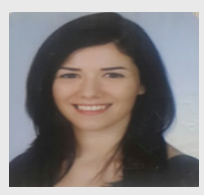

Merve Uzun: Has received her MSc in Pharmaceutical Botany at Faculty of Pharmacy-Anadolu University. Now she is a pharmacist in Antalya.

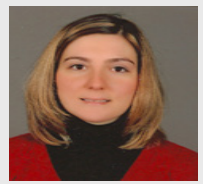

Nagehan Saltan: She is a specialist in Pharmaceutical Botany at Faculty of Pharmacy-Anadolu University. Has received her MSc in the same place.

Cite this article: Köse YB, Uzun M, Saltan N. Heavy Metal Contents Of Melissa Which Is Sold In Herbalists. Indian $\mathrm{J}$ of Pharmaceutical Education and Research. 2017;51(3)Suppl:S217-20. 